\title{
1,1-Diphenyl-2-picrylhydrazyl radical scavenging activity of novel dihydropyridine derivatives
}

\author{
Ayaz Anwar a, Abdul Hameed a,*, Shahida Perveen a, Maliha Uroos b, \\ Muhammad Iqbal Choudhary a,c and Fatima Zahra Basha a \\ a Husein Ebrahim Jamal Research Institute of Chemistry, International Centre for Chemical and Biological Sciences, University of Karachi, Karachi-75270, Pakistan \\ $\mathrm{b}$ Institute of Agricultural Sciences, University of the Punjab, Quaid-e-Azam Campus, Lahore, 54590 Pakistan \\ ' Department of Biochemistry, Faculty of Science, King Abdulaziz University, Jeddah-21412, Saudi Arabia \\ ${ }^{*}$ Corresponding author at: Husein Ebrahim Jamal Research Institute of Chemistry, International Centre for Chemical and Biological Sciences, University of Karachi, \\ Karachi-75270, Pakistan. \\ Tel.: +92.219.9261701-2/Ext.240. Fax: +92.213.4819018. E-mail address: abdul hameed8@hotmail.com (A. Hameed).
}

\section{COMMUNICATION INFORMATION}

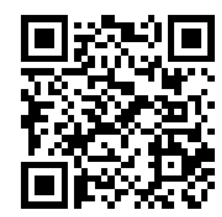

DOI: $10.5155 /$ eurjchem.5.1.189-191.916

Received: 04 September 2013

Received in revised form: 25 October 2013

Accepted: 26 October 2013

Online: 31 March 2014

\section{KEYWORDS}

\section{Oxidative stress}

Antioxidant activity

Reactive oxygen species

DPPH radical scavengers

Knoevenagel condensation

Dihydropyridine derivatives

\section{Introduction}

Free radicals, generated during oxidative biochemical processes, can cause many damages to the living systems $[1,2]$. The over-production of reactive oxygen species (ROS) or weakening of antioxidant defence systems results in oxidative stress which leads to onset of premature aging, cancer and asthma [3-5]. The interaction of free radicals with polyunsaturated fatty acid causes cerebral ischemia and other CNS disorders [6]. Literature showed examples of antioxidants agents bearing aromatic rings, which can inhibit the cellular oxidative damages [7,8]. About 4,000 diverse polyphenols display antioxidant activity in vitro, but their antioxidant effects in vivo were found to be significantly low $[9,10]$. Although oxidative reactions are important for physiological function, but the formation of free radicals initiates many undesired reactions in cell, which can lead to cell damage or death. Antioxidants can donate electrons to free radical species and convert them into harmless molecules, and thus prevent cells from oxidative damage [11,12]. Hashida et al. demonstrated that the proliferation of metastatic tumor cells can be ceased by the detoxification of hydrogen peroxide with pegylated catalase
[13]. Thus the application of antioxidants to prevent tumor cells progression is an important approach in current drug discovery and developments.

Heterocyclic compounds, particularly the pyridine ring bearing molecules, have a wide range of applications in medicinal chemistry [14]. Cominacinio et al. [15] reported the antioxidant properties of different 1,4-dihydrpyridine derivatives. Lacidipine (II) reduced the concentration of ROS in bovine aortic endothelial cells (BAECs). The antioxidant role of some other types of 1,4-dihydropridine derivatives has been reviewed by Augustyniak et al. [16]. We have recently reported the synthesis of 5,6-dihydropyridine derivatives via a solvent free conditions [17]. The antioxidant activity of 1,4dihydropyridines derivatives encouraged us to evaluate the antioxidant properties of new 5,6-dihydropyridine derivatives (I), having C-4 and C-6 substituted benzene rings (Figure 1). The 5,6-dihydropyridine derivatives were prepared via a solvent free method in 52-95 \% yields, as shown in Scheme 1. All the synthesized dihydropyridine derivatives (1-13) were tested against DPPH which showed a wide range of radical scavenging activity ( $\mathrm{IC}_{50}$ value from 127.4 to $284.5 \mu \mathrm{M}$ ) due to different substituents on the phenyl ring. 
Table 1. In vitro DPPH free radical scavenging assay.

\begin{tabular}{|c|c|c|c|c|}
\hline Compounds & $\mathbf{R}^{\mathbf{1}}$ & $\mathbf{R}^{2}$ & Yield (\%) [17] & $\mathrm{IC}_{50}(\mu \mathrm{M} \pm \mathrm{SEM}$ a $)$ \\
\hline 1 & $\mathrm{H}$ & $\mathrm{H}$ & 98 & $\mathrm{NA}^{\mathrm{b}}$ \\
\hline 2 & $\mathrm{H}$ & $\mathrm{Me}$ & 95 & $284.5 \pm 0.66$ \\
\hline 3 & $\mathrm{H}$ & $\mathrm{OH}$ & 75 & $228.2 \pm 3.36$ \\
\hline 4 & $\mathrm{OH}$ & $\mathrm{H}$ & 93 & $223.8 \pm 3.30$ \\
\hline 5 & $\mathrm{H}$ & $\mathrm{OMe}$ & 95 & $161.4 \pm 2.81$ \\
\hline 6 & $\mathrm{OMe}$ & $\mathrm{H}$ & 80 & $142.2 \pm 0.60$ \\
\hline 7 & $\mathrm{H}$ & $\mathrm{F}$ & 75 & $172.8 \pm 1.72$ \\
\hline 8 & $\mathrm{~F}$ & $\mathrm{H}$ & 75 & $127.4 \pm 3.50$ \\
\hline 9 & $\mathrm{H}$ & $\mathrm{Cl}$ & 90 & $164.6 \pm 4.50$ \\
\hline 10 & $\mathrm{H}$ & $\mathrm{Br}$ & 90 & $144.7 \pm 2.46$ \\
\hline 11 & $\mathrm{Br}$ & $\mathrm{H}$ & 90 & $132.5 \pm 3.32$ \\
\hline 12 & $\mathrm{H}$ & I & 89 & $153.7 \pm 0.50$ \\
\hline 13 & & & 65 & $196.3 \pm 6.5$ \\
\hline \multirow{2}{*}{\multicolumn{3}{|c|}{$\begin{array}{l}\text { Ascorbic acid (AS)c } \\
\text { Butylated hydroxyanisole (BHA)c }\end{array}$}} & & $40.6 \pm 1.2$ \\
\hline & & & & $44.7 \pm 0.67$ \\
\hline
\end{tabular}

a SEM is the standard error of the mean.

bNA: Not active.

c Standard inhibitor for DPPH radical scavenging activity.

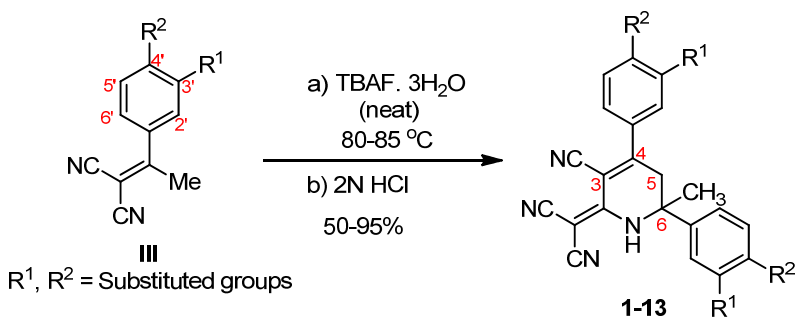

Scheme 1<smiles>[R]c1ccc(C2=C(C#N)C(=C(C#N)C#N)NC(C)(c3ccc([R])c([R])c3)C2)cc1[R]</smiles>

$R^{1}, R^{2}=$ Substituted groups<smiles>CCOCC1=C(C)NC(C)=C(C(=O)OCC)C1c1ccccc1C=CC(=O)OCC</smiles>

Figure 1. Dihydropyridines I and II.

\section{Experimental}

\subsection{Chemistry}

The details of general procedure for the synthesis of dihydropyridine analogues have been published in our previous publication [17]. A schematic layout of the reaction is shown in Scheme 1.

\subsection{1,1-Diphenyl-2-picrylhydrazyl (DPPH) free radical scavenging assay (in vitro)}

The antioxidant activity of dihydropyridine derivatives against 1,1-diphenyl-2-picrylhydrazil (DPPH) radical was determined by following literature protocol [18]. A $5 \mu \mathrm{L}$ each test sample (0.5 mM in DMSO) was mixed with $95 \mu \mathrm{L}$ DPPH solution in ethanol. The resulting mixture was incubated for 30 minutes at $37^{\circ} \mathrm{C}$ after adding into 96 -well microtiter plate. The absorbance was monitored with microplate SpectraMax 340, applied Biosystems, CA, USA, reader at $515 \mathrm{~nm}$. In radical form, DPPH solution in ethanol has strong violet colour, while when react with antioxidant, the colour changed to pale yellow with decreased in absorbance. The percent radical scavenging activity of each antioxidant was measured in comparison of a DMSO control (Table 1). The IC 50 values were calculated by EZFit enzyme kinetics software program (Perrella Scientific Inc. Amherst, MA, USA) (Table 1). Ascorbic acid and butylated hydroxyanisole (BHA) were used as standard inhibitors in $\mathrm{DPPH}$ radical scavenging assay.

\section{Results and discussion}

The synthesis of dihydropyridine derivatives $\mathbf{1 - 1 3}$ is presented Figure 1 [17]. Their structures were deduced by a combination of IR, NMR and mass spectroscopy. Analogues 113 were subjected to in vitro DPPH radical scavenging assay and results are presented in Table 1.

Dihydropyridine derivatives 1-13 exhibited a varied range of IC 50 values $127.4 \pm 3.5$ to $284.5 \pm 0.66 \mu \mathrm{M}$ (Table 1 ). The 3 'fluoro $\mathbf{8}\left(\mathrm{IC}_{50}=127.4 \pm 3.5 \mu \mathrm{M}\right), 3$ '-bromo $\mathbf{1 1}\left(\mathrm{IC}_{50}=132.5 \pm 3.32\right.$ $\mu \mathrm{M}), 3^{\prime}$-methoxy $6\left(\mathrm{IC}_{50}=142.2 \pm 0.60 \mu \mathrm{M}\right), 4^{\prime}$-bromo $10\left(\mathrm{IC}_{50}=\right.$ $144.7 \pm 2.46 \mu \mathrm{M}), 4^{\prime}$-iodo $12\left(\mathrm{IC}_{50}=153.7 \pm 0.50 \mu \mathrm{M}\right), 4^{\prime}-$ methoxy $5\left(\mathrm{IC}_{50}=161.4 \pm 2.81 \mu \mathrm{M}\right)$ and 3 '-chloro $5\left(\mathrm{IC}_{50}=164.4 \pm 2.50\right.$ $\mu \mathrm{M})$ derivatives exhibited moderate activity, while 4 '-fluoro 7 
$\left(\mathrm{IC}_{50}=172.8 \pm 1.72 \mu \mathrm{M}\right), \mathbf{1 3}\left(\mathrm{IC}_{50}=196.3 \pm 6.5 \mu \mathrm{M}\right), \mathbf{4}\left(\mathrm{IC}_{50}=\right.$ $223.8 \pm 3.30 \mu \mathrm{M}), 3\left(\mathrm{IC}_{50}=228.2 \pm 3.36 \mu \mathrm{M}\right)$ and $2\left(\mathrm{IC}_{50}=\right.$ $284.5 \pm 0.66 \mu \mathrm{M}$ ) displayed low activity, when compared to standards inhibitors ascorbic acid ( $\mathrm{IC}_{50}=40.6 \pm 1.2 \mu \mathrm{M}$ ) and butylated hydroxyanisole $\left(\mathrm{IC}_{50}=40.6 \pm 1.2 \mu \mathrm{M}\right)$. The phenyl derivative 1 found to be non-active in the series 1-13 (Figure 2).

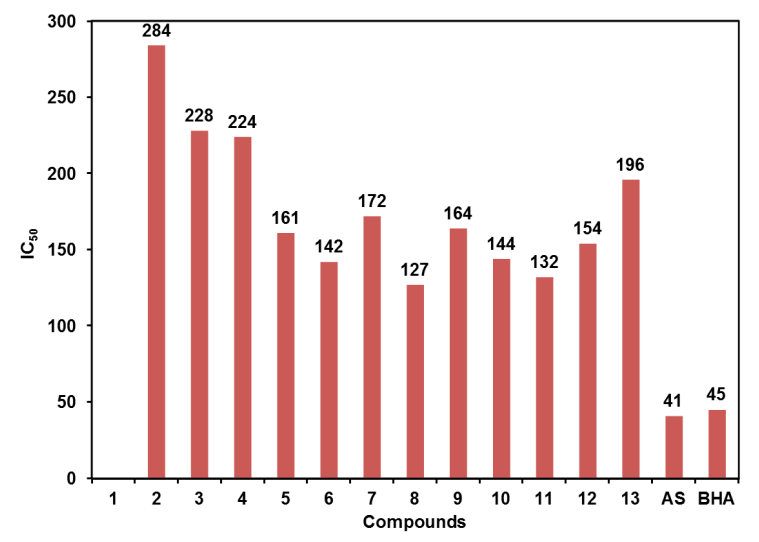

Figure 2. $\mathrm{IC}_{50}$ values of dihydropyridine derivatives 1-13

Radical scavenging activity of each dihydropyridine derivative (1-13) generally depends on the formation and stabilization of resulting free radical species. A structureactivity relationship of dihydropyridine derivatives showed that 3'-fluoro $8\left(\mathrm{IC}_{50}=127.4 \pm 3.5 \mu \mathrm{M}\right), 3$ '-bromo $\mathbf{1 1}\left(\mathrm{IC}_{50}=\right.$ $132.5 \pm 3.30 \mu \mathrm{M})$ and 3 '-methoxy $6\left(\mathrm{IC}_{50}=142.2 \pm 0.60 \mu \mathrm{M}\right)$ derivatives exhibited potent a activity. This may be due to the formation of free radicals at electron rich centers, such as oxygen atoms. A slight decline in activity was observed in 4'fluoro $7 \quad\left(\mathrm{IC}_{50}=172.8 \pm 1.72 \mu \mathrm{M}\right), 44^{\prime}$-bromo $\mathbf{1 0}\left(\mathrm{IC}_{50}=\right.$ $144.7 \pm 2.46 \mu \mathrm{M}), 4{ }^{\prime}-$ mthoxy $5\left(\mathrm{IC}_{50}=161.4 \pm 2.81 \mu \mathrm{M}\right), 4^{\prime}$-chloro $9\left(\mathrm{IC}_{50}=164.6 \pm 4.50 \mu \mathrm{M}\right)$ and 4 '-iodo $12\left(\mathrm{IC}_{50}=153.7 \pm 0.50 \mu \mathrm{M}\right)$ derivatives, as compared to their 3 '-phenyl substituted derivatives 8, 11 and 6, possibly due to the $p$-substituted groups of dihydropyridine derivatives.

The hydroxy-substituted analogues 3 (4'-hydroxy) and 4 (3'-hydroxy) showed $\mathrm{IC}_{50}$ values $228.2 \pm 30 \mu \mathrm{M}$ and $223.8 \pm 30$ $\mu \mathrm{M}$, respectively. Generally, the polyphenolic compounds exhibit good antioxidant activity due to stable phenoxide radical, produced by the abstraction of hydrogen atom by DPPH. However the free radical scavenging activity of our 4'hydroxy $\mathbf{3}$ and 3'-hydroxy $\mathbf{4}$ is found to be lower than the other derivatives in the series. This may be due to stabilization of phenoxide species of these molecules. The DPPH scavenging activity of 4 '-methyl derivative $2\left(\mathrm{IC}_{50}=284.5 \pm 0.66 \mu \mathrm{M}\right)$ was also found to be low, may be due to electron denoting effect of methyl substituent. This study identifies a new class of compounds with potent DPPH radical scavenging activity. Compound $\mathbf{8}$ could serve as lead for further development as an antioxidant.

\section{Conclusion}

The dihydropyridine derivatives 1-13 were identified as a new class of antioxidants. Their $\mathrm{IC}_{50}$ values were found to dependent upon the electronic effect of substituents present on the phenyl rings. The 3 '-fluoro phenyl analogue $\mathbf{8}$ was found to be the most active in the series of dihydropyridine derivatives (Table 1). These compounds could serve as lead molecules in the development of new antioxidant with therapeutic potential.

\section{Acknowledgements}

We are thankful to Higher Education Commission (HEC), Pakistan and Husein Ebrahim Jamal Research Institute of Chemistry, International Center for Chemical and Biological Sciences, University of Karachi, Karachi-75270, Pakistan for providing financial support.

\section{References}

[1]. Cui, H.; Kong, Y.; Zhang, H. J. Signal Transduct. 2012, 2012, 646-354

[2]. Beckman, K. B.; Ames, B. N. Physiol. Rev. 1998, 78, 547-581.

[3]. Martinez-Martinez, F.; Razo-Hernandez, R.; Peraza-Campos, A Villanueva-Garcia, M.; Sumaya-Martinez, M.; Cano, D.; GomezSandoval, Z. Molecules 2012, 17, 14882-14898.

[4]. Meyer, A. S.; Heinonen, M.; Frankel, E. N. Food Chem. 1998, 61, 71-75.

[5]. Hunt, E. J.; Lester, C. E.; Lester, E. A.; Tackett, R. L. Life Sci. 2001, 69, 181-190.

[6]. Schmidley, J. W. Stroke 1990, 21, 1086-1090.

[7]. Rice-Evans, C. A.; Miller, N. J.; Paganga, G. Free Radical Biol. Med. 1996, 20, 933-956.

[8]. Villano, D.; Fernandez-Pachon, M. S.; Moya, M. L.; Troncoso, A. M Garcia-Parrilla, M. C. Talanta 2007, 71, 230-235.

[9]. Williams, R. J.; Spencer, J. P. E.; Rice-Evans, C. Free Radical Biol. Med. 2004, 36, 838-849.

[10]. Ajitha, M. J.; Mohanlal, S.; Suresh, C. H.; Jayalekshmy, A. J. Agric. Food Chem. 2012, 60, 3693-3699.

[11]. Moure, A.; Cruz, J. M.; Franco, D.; Dominguez, J. M.; Sineiro, J.; Dominguez, H.; Jose Nunez, M. A.; Parajo, J. C. Food Chem. 2001, 72, 145-171.

[12]. Holiman, P. C. H.; Hertog, M. G. L.; Katan, M. B. Food Chem. 1996, 57, 43-46.

[13]. Hyoudou, K.; Nishikawa, M.; Kobayashi, Y.; Umeyama, Y.; Yamashita, F.; Hashida, M. Free Radical Biol. Med. 2006, 41, 1449-1458.

[14]. Chaubey, A.; Pandeya, S. N. Asian J. Pharm. Clin. Res. 2011, 4, 5-8.

[15]. Cominacini, L.; Fratta Pasini, A.; Garbin, U.; Pastorino, A. M.; Davoli, A.; Nava, C.; Campagnola, M.; Rossato, P.; Lo Cascio, V. Biochem. Biophys. Res. Commun. 2003, 302, 679-684.

[16]. Augustyniak, A.; Bartosz, G.; Cipak, A.; Duburs, G.; Horakova, L.; Luczaj, W.; Majekova, M.; Odysseos, A. D.; Rackova, L.; Skrzydlewska, E.; Stefek, M.; Strosova, M.; Tirzitis, G.; Venskutonis, P. R.; Viskupicova, J.; Vraka, P. S.; Zarkovic, N. Free Radical Res. 2010, 44, 1216-1262.

[17]. Hameed, A.; Anwar, A.; Yousaf, S.; Khan, K. M.; Basha, F. Z. Eur. J. Chem 2012, 3, 179-185.

[18]. Thadhani, V. M.; Choudhary, M. I.; Ali, S.; Omar, I.; Siddique, H.; Karunaratne, V. Nat. Prod. Res. 2011, 25, 1827-1837. 